\title{
Overview of Nutritional Status in Schizophrenic Patients at Dr. Soeharto Heerdjan Grogol Hospital in 2019
}

\author{
Ance Adriani \\ Department of Medical Community, Medical Faculty, Universitas Kristen Indonesia, Jakarta, Indonesia
}

\begin{abstract}
Nutritional status is a state of health due to interactions between food, the human body and the human environment. If lack of nutrients, the body will be more easily infected. Nevertheless, more nutrition can also be detrimental because it can lead to degenerative diseases. Therefore, it is crucial to maintain a balanced intake of nutrients following the body's needs. This study discusses the description of the nutritional status of schizophrenic patients at the Mental Hospital Dr. Soeharto Heerdjan Grogol in 2019. This study used a descriptive observational research method to see the nutritional status and food intake of inpatient schizophrenia patients. One hundred fifty-five schizophrenia patients were hospitalized. The results showed more male patients than female patients. Changes in weight in schizophrenia patients increase more than is reduced. The most nutritional status of schizophrenia patients is good. Patients with malnutrition are $12.9 \%$. Many patients leave $<25 \%$ food. Patients with good nutrition are primarily found in the Peacock Room, which is an independent patient room.
\end{abstract}

Keywords: Schizophrenia, Nutritional Status, Malnutrition, Food Intake

\section{INTRODUCTION}

Schizophrenia is a mental disorder of unknown cause and has a broad disease course, with varying symptoms [1], and it is a chronic mental health disorder with characteristic symptoms such as delusions, hallucinations, disorganized behaviour and speech, and impaired cognitive abilities [2]. Schizophrenia is the most common disease in the group of mental disorders. Schizophrenic patients worldwide are 21 million people. Severe mental disorders prevalence, such as schizophrenia, reaches around 400,000 people or as much as 1.7 per 1,000 population [3].

According to Sadock, the prevalence of schizophrenic patients is equal in males and females, while other books say the prevalence of schizophrenic patients is more male than female $[1 ; 4]$. The most common age in schizophrenic patients is 18 to 25 years for men and 25 to 35 years for women [5]. Age is rarely found in patients diagnosed under the age of 18 years or over 40 years. Schizophrenia can start from family or people around who are aware of changes in the patient's attitude and behaviour [6]. On average, schizophrenic patients come with complaints of eating disorders [7]. Schizophrenic patients can recover completely or be returned to social groups, but there are few disabilities. Patients diagnosed within the first year will make a full recovery. Schizophrenic patients have decreased ability to care for themselves, such as meeting daily needs. Patients become lazy to bathe, lazy to eat, lazy to change clothes, lazy to socialize, lazy to work, and others [8]. The eating pattern of schizophrenic patients (how to eat and appetite) depends on their emotional 
state [9]. Patients need the help of others to care for themselves.

Nutritional status as a balance between the amount of nutrient intake and the amount required by the body for various biological functions such as physical growth, development, activity or productivity, health maintenance and others [10]. Adequacy of nutrients is adjusted to the age group, gender, and physiological conditions (pregnant and lactating women). Several factors affect a person's nutritional adequacy, namely the stage of growth and development of the body, body size and composition, gender, state of body health, physiological state of the body, physical activity, environment, food quality, and lifestyle [11].

Nutritional status is divided into poor nutrition, less nutrition, good nutrition and over nutrition [12]. If there is a lack of nutrients, the body will be more easily infected. However, excess nutrition can also be detrimental because it can lead to degenerative diseases. It is crucial to maintain a balanced intake of nutrients following the body's needs. Schizophrenic patients with decreased ability to care for themselves lose their appetite or find it difficult to eat, maybe malnourished. This difficult eating habit can cause the patient's nutritional status to become malnourished or even malnourished.

Based on this background, the authors are interested in conducting a study entitled "Overview of Nutritional Status in Schizophrenic Patients at Dr Soeharto Heerdjan Grogol Hospital in 2019". The problem solved in this research is conceptualized in the form of the following questions: "how is the picture of nutritional status in schizophrenic patients?" intending to describe the nutritional status of schizophrenic patients treated at the Mental Hospital dr. Suharto Heerdjan Grogol.

\section{LITERATURE REVIEW}

The term schizophrenia comes from Greek, namely schizo, which means split, while phren means mind [5]. So it can be interpreted that schizophrenic patients have divided minds. Schizophrenia is a psychiatric disease of unknown cause and has a broad course of the disease, with varying symptoms. This disorder is a significant psychosis that can manifest in various ways [13]. Schizophrenia is a different matter with multiple personalities. Schizophrenia is included in the category of severe mental disorders [1].

The aetiology of schizophrenia is unknown, but there are several theories related to schizophrenia, the first theory is hereditary [14]. In a study of twins raised in different environments, each child was diagnosed with schizophrenia, and the twin brother was also diagnosed with schizophrenia. Genetic factors are greater than environmental factors. Hereditary in schizophrenia is about 80-85\% [15]. It is not known how genes affect the course of schizophrenia. Genetic inheritance carries a greater risk [13]. Another theory says that the cause of schizophrenia is pathognomonic of the brain, namely abnormalities in the limbic system, frontal cortex, cerebellum, and basal ganglia [1; 14]. Structural nerve imaging with pneumoenselography, CT-scan, and MRI shows that some schizophrenic patients experience cerebral ventriculus enlargement. It is also said that schizophrenic patients have an excess of certain neurotransmitters [16]. As with the dopamine overload hypothesis, serotonin antagonists may suppress psychotic symptoms, GABA deficiency and antagonist hypotheses may produce schizophrenia-like syndrome. Two observations, namely the administration of psychotic drugs (neuroleptic) that block dopamine receptors, affect the treatment of schizophrenia, and amphetamine drugs that increase dopamine activity, can cause positive symptoms in schizophrenia $[1 ; 13]$. The psychological theory assumes stress can cause schizophrenia in some people who have a specific vulnerability if given psychological pressure, which can cause symptoms of schizophrenia [1]. 
Symptoms of Schizophrenia - Symptoms of schizophrenia, according to Bleuler, are divided into primary symptoms and secondary symptoms [8]. The primary symptoms are thought process disorders, emotional disturbances, will disorders, and autism. Secondary symptoms include delusions, hallucinations, and impaired motor function. Primary symptoms have no known cause, while secondary symptoms are the body's way of adjusting to the primary disorder. According to T. J. Crow, schizophrenia is distinguished by positive symptoms and negative symptoms [1]. Positive symptoms cannot be felt or experienced in healthy people but are present in schizophrenic patients. Negative symptoms are things that healthy people can do but are reduced in schizophrenic patients. Positive symptoms are delusions and hallucinations, while negative symptoms include alogia, lack of self-care, lack of motivation, anhedonia, social withdrawal. Type I schizophrenia shows more positive symptoms. In type II, negative symptoms appear more than positive symptoms. Based on DSM-IV-TR, the classification of schizophrenia subtypes is paranoid, disorganized, catatonic, not classified, and residual. This classification is based on clinical manifestations. This difference in subtypes does not make a definite difference in prognosis [1].

Nutritional status is a state of health due to the interaction between food, the human body and the human environment [17]. Nutritional status is an expression of balance in certain variables or the manifestation of nutrition in the form of certain variables [11]. According to the Ministry of Health of the Republic of Indonesia, nutritional status is a balance between the amount of nutrient intake and the amount required by the body for various biological functions such as physical growth, development, activity or productivity, health maintenance and others. Nutritional status is divided into poor nutritional status, poor nutrition, good nutrition, and overnutrition [12].
Undernutrition means that the intake of nutrients is less than the needs, while the nutritional intake of more nutrients is more than their needs. If the nutritional status is not good (undernutrition or overnutrition), it negatively impacts the body.

Factors that affect the nutritional status of adults consist of direct and indirect causes. Direct causes of nutritional problems include nutritional intake and infectious diseases. Indirect factors that cause nutritional problems are physical activity and body growth patterns [18]. Low nutritional intake causes nutritional status to be less, while high nutritional intake causes nutritional status to become more. Food intake is associated with dopamine release and feelings of satisfaction when consuming food [19]. Infectious diseases can affect nutritional statuses, such as gastrointestinal tract infections causing diarrhoea and vomiting, or respiratory tract infections, decreasing appetite [20]. As stated by Almatsier, nutritional status is divided into four groups. The following nutritional status is grouped according to WHO-NCHS: poor nutrition, poor nutrition, good nutrition, and over nutrition.

To assess nutritional status, it is necessary to obtain objective and subjective data. The assessment components include food intake, biochemical examination, biophysical examination, clinical examination, and anthropometry [21]. To find out the food intake, the things that need to be asked through the history are the food type and amount that has been consumed. However, there are many obstacles to knowing food intakes, such as forgetting the consumed food type or amount. In addition, the list of available food compositions is not complete with the increasing number of new food variants, cooking methods, and places for growing vegetables and fruit are different for each region, and the calculation of nutrient content is not accurate. Assessment of nutritional status is divided into direct and indirect [22]. Direct assessment includes anthropometric examination, biochemical examination, 
clinical examination, and biophysical examination. Indirect assessments include surveys of food consumption, vital statistics, and ecological factors.

Anthropometric examination - Physical growth patterns and proportions of body tissues (Fat, muscle, and the amount of water in the body) describe protein and energy intake [11]. The anthropometric examination helps measure body composition. Although gender and genetics also influence growth, the most crucial thing is nutrient intake. The anthropometric examination includes height, weight, changes in body weight, body circumference, head circumference, chest circumference, arm circumference, waist circumference, hip circumference, and body mass index. Changes in body weight of $10 \%$ or more indicate a health problem. The formula $\mathrm{BMI}=\mathrm{BB} / \mathrm{TB} 2$ can be used to measure BMI, with weight units in kilograms and height in meters. This formula is only used for ages 19 to 70 years with a normal spine. This formula cannot measure the BMI of athletes, bodybuilders, pregnant or lactating women. Based on the results of the BMI calculation, nutritional status can be grouped.

\section{Biochemical Examination - Protein} parameters to assess nutritional status are visceral protein and somatic protein. Visceral proteins include serum albumin, albumin, transferrin, lymphocyte count, and skin antigen testing. Somatic protein can also be calculated by measuring the midupper arm circumference.

\section{Clinical Examination and Medical} History - Includes a thorough physical examination. Things to note are the gums, teeth, tongue, eyes, skin, and genitals (only for men). Other tests such as anthropometry and biochemistry are needed to distinguish pathognomonic due to nutritional deficiency from other causes.
Biophysical Examination - Includes a test of the ability of tissue function and test of changes in the structure of the tissue. There are three ways to assess tissue function and structural changes, namely radiological examination, physical function examination, and cytology. Examination of physical function, such as adaptation tests in the darkroom. The cytological examination is like looking at stains on the epithelium of the oral mucosa.

Food Consumption Survey - Inadequate nutritional intake affects nutritional status to be less good. The current lack of nutritional intake does not directly indicate the nutritional status of being undernourished or well-nourished at this time. Nutrients that have been consumed take time to metabolize in the body until they can finally be used by the body [23]. There are several methods of surveying food consumption, divided into direct and indirect. Direct methods include food records, dietary history, food frequency questionnaire, food recall 24 hours, and food weighing. Indirect methods include the food account, namely the amount of food consumed on a household scale, and the food balance sheet, namely food consumption on a national scale [24].

\section{RESEARCH METHOD}

This study used a descriptive observational research method to describe the nutritional status of schizophrenic patients at the Mental Hospital of dr. Suharto Heerdjan Grogol. The research was conducted at the Mental Hospital dr. Suharto Heerdjan Grogol, West Jakarta. The time of the study was carried out in September - October 2019. The population in this study were all schizophrenic patients who were hospitalized during the study at dr. Suharto Heerdjan Grogol, West Jakarta. The population includes adult patients. The sample in this study were patients who met the research criteria in this study using medical record data and direct observation. For direct observation, the tools and 
materials needed are tables of patient leftovers. To find out the type and amount of food provided by the hospital, it was obtained from the data provided by the nutrition installation. Data were obtained in two ways, namely from primary data and secondary data. Primary data is direct observation at the Mental Hospital dr. Suharto Heerdjan, and secondary data in the form of medical records of the Mental Hospital of dr. Suharto Heerdjan. Food intake data was obtained by the difference between the amount of food provided by the hospital nutrition installation and the amount of food eaten by the patient based on the Comstock method. Food intake is then analyzed to convert it into nutrients in energy, carbohydrates, protein, and Fat using the Nutri survey program. Processing and analysis of the overall data in this study using the SPSS program with univariate analysis.

\section{RESULT AND DISCUSSION}

The research was conducted at the Mental Hospital dr. Suharto Heerdjan on hospitalized schizophrenic patients in October 2019. Data were obtained from medical records and direct observation. Medical record data retrieval was carried out during September - October 2019, while direct observation in recording the patient's leftover food was carried out from Saturday 12 October to Wednesday 16 October 2019. The results of this study obtained 163 inpatients. In this study, 155 people met the inclusion criteria. There are 3 VIP patients and five isolation patients - schizophrenic patients at the Mental Hospital dr. Suharto Heerdjan, who met the inclusion criteria, had several characteristics noted in this study. The characteristics of the respondents in this study were gender, height, weight, and changes in body weight.

This study was conducted on respondents who met the inclusion criteria regardless of gender. So, the respondents of this study included male and female schizophrenic patients who were hospitalized. The number of male and female patients can be seen in table 1, patients with mental disorders at the Mental Hospital dr. Suharto Heerdjan hospitalization is divided into nine rooms: 4 male rooms, three female rooms, and two mixed rooms.

This study was conducted regardless of the capacity provided by the hospital, even though the hospital provided more male capacity than female. Each room is filled with people with mental health conditions with different mental disorders diagnoses. The rooms are divided based on the degree of the patient's condition, namely the preparation room for discharge, the intermediate room, and the heated room. One home preparation room consists of men and women, namely patients who have entered the independent stage. There are two heated rooms for male patients, namely patients with acute conditions, and two intermediate rooms, namely patients whose condition has improved but is still prone to restlessness. For female patients, it is not divided based on the degree of the patient's mental condition. The hospital dr. Suharto Heerdjan provides one particular room for ODGJ with physical illness. The number of patients in each room can be seen in table 10.

Table 1. Gender Distribution of Respondents

\begin{tabular}{|l|l|l|}
\hline & $\mathbf{N}$ & $\mathbf{\%}$ \\
\hline Male & 104 & $67.1 \%$ \\
\hline Female & 51 & $32.9 \%$ \\
\hline Total & 155 & $100 \%$ \\
\hline
\end{tabular}

Based on the results of this study, schizophrenic patients were hospitalized at the Mental Hospital dr. Suharto Heerdjan Grogol in October 2019, more men than women. As much as $67.1 \%$ with a total of 104 people from 155 people. There are $32.9 \%$ as many as 51 female patients who have schizophrenia.

Height and Weight - To determine the nutritional status of patients assessed based on BMI, calculated from height and weight. In this study, the height and weight of the respondents can be seen in the appendix. The average, minimum, and maximum 
Ance Adriani. Overview of nutritional status in schizophrenic patients at Dr Soeharto Heerdjan Grogol Hospital in 2019.

height and weight of the respondents can be seen in table 2.

Table 2. Distribution of Respondents' Height and Weight

\begin{tabular}{|l|l|l|}
\hline & Body Height $(\mathbf{c m})$ & Body Weight $(\mathbf{k g})$ \\
\hline Average & 161.49 & 59.283 \\
\hline Smallest & 143 & 36.1 \\
\hline Greatest & 186 & 132.5 \\
\hline
\end{tabular}

Based on the study results, the average height of the patient was 161.49 $\mathrm{cm}$, while the average weight of the patient was $59.2 \mathrm{~kg}$. The shortest patient's height was $143 \mathrm{~cm}$, while the tallest was $186 \mathrm{~cm}$. The patient's lightest weight was $36.1 \mathrm{~kg}$, while the heaviest was $132.5 \mathrm{~kg}$.

Changes in Body Weight - Inpatients at the Mental Hospital dr. Suharto Heerdjan was hospitalized for an average of 21 days. Changes in the patient's weight can be seen in table 3 or more fully in the appendix.

Table 3. Changes in Body Weight

\begin{tabular}{|l|l|l|}
\multicolumn{3}{|c|}{ Table 3. Changes in Body Weight } \\
\hline BW Lose & N & \% \\
\hline BW Gain & 26 & $16.8 \%$ \\
\hline Total & 129 & $83.2 \%$ \\
\hline
\end{tabular}

Changes in body weight in respondents by $16.8 \%$ lost weight, while $83.2 \%$ gained weight. At mealtime, patients who have no appetite are persuaded by medical personnel to finish their food. It is possible that after the patient is admitted to the hospital, the patient's weight increases.

Table 4. Difference between Final Body Weight and Initial Body Weight

\begin{tabular}{|l|l|}
\hline & Weight Unit \\
\hline Average Body Weight Change & $0,3 \mathrm{~kg}$ \\
\hline Most widely & $0,3 \mathrm{~kg}$ \\
\hline Biggest Body Weight Loss & $1,4 \mathrm{~kg}$ \\
\hline Biggest Body Weight Gain & $1,5 \mathrm{~kg}$ \\
\hline
\end{tabular}

Based on the results of the study, the average schizophrenic patient increased weight by $0.3 \mathrm{~kg}$.

The study of the most significant weight loss of $1.4 \mathrm{~kg}$ and the most prominent weight gain of $1.5 \mathrm{~kg}$ can be seen in Tables 5 and 6. It may be due to the first weight examination and the most recent examination in a short period, so there are not many bodyweight changes.
Table 5. Distribution of Respondents' Weight Loss

\begin{tabular}{|l|l|l|}
\hline Weight loss & N & \% \\
\hline $0,2 \mathrm{~kg}$ & 1 & $4 \%$ \\
\hline $0,3 \mathrm{~kg}$ & 3 & $11 \%$ \\
\hline $0,4 \mathrm{~kg}$ & 3 & $11 \%$ \\
\hline $0,5 \mathrm{~kg}$ & 11 & $42 \%$ \\
\hline $0,6 \mathrm{~kg}$ & 3 & $11 \%$ \\
\hline $0,7 \mathrm{~kg}$ & 1 & $4 \%$ \\
\hline $0,8 \mathrm{~kg}$ & 2 & $9 \%$ \\
\hline $0,9 \mathrm{~kg}$ & 1 & $4 \%$ \\
\hline $1,4 \mathrm{~kg}$ & 1 & $4 \%$ \\
\hline Total & 26 & $100 \%$ \\
\hline
\end{tabular}

Table 6. Distribution of Respondents Weight Gain

\begin{tabular}{|l|l|l|}
\hline Weight Gain & N & Persentase \\
\hline 0,2 & 9 & $7 . \%$ \\
\hline 0,3 & 30 & $23.3 \%$ \\
\hline 0,4 & 28 & $21.7 \%$ \\
\hline 0,5 & 22 & $17.1 \%$ \\
\hline 0,6 & 24 & $18.6 \%$ \\
\hline 0,7 & 8 & $6.2 \%$ \\
\hline 0,8 & 2 & $1.6 \%$ \\
\hline 0,9 & 3 & $2.3 \%$ \\
\hline 1,2 & 2 & $1.6 \%$ \\
\hline 1,5 & 1 & $0.8 \%$ \\
\hline Total & 129 & $100 \%$ \\
\hline & &
\end{tabular}

Weight gain of $0.2 \mathrm{~kg}$ occurred in 9 people, while weight loss of $0.2 \mathrm{~kg}$ occurred in 1 person. Likewise, an increase in body weight of $0.3 \mathrm{~kg}$ occurred in 30 people, while a decrease of $0.3 \mathrm{~kg}$ occurred in 3 people.

Nutritional status as the dependent variable in this study was divided into 3 points: undernutrition, good nutrition, and overnutrition. The nutritional status assessed based on the BMI of the respondents in this study can be seen in table 7 and table 8 . The nutritional status of each patient can be seen in the appendix.

Table 7. Distribution of Respondents Nutritional Status

\begin{tabular}{|l|l|l|}
\hline & $\mathbf{N}$ & $\mathbf{\%}$ \\
\hline Less & 20 & 12.9 \\
\hline Good & 108 & 69.7 \\
\hline More & 27 & 17.4 \\
\hline Total & 155 & 100.0 \\
\hline
\end{tabular}

Based on the results of this study, the nutritional status of schizophrenic patients at the Mental Hospital dr. Suharto Heerdjan Grogol in October 2019 had the better nutrition at $69.7 \%$ with a total of 108 people. Overnutrition ranks second at $17.4 \%$, while the lowest nutritional status is undernutrition $(12.9 \%)$, with a total of 20 people. 
Ance Adriani. Overview of nutritional status in schizophrenic patients at Dr Soeharto Heerdjan Grogol Hospital in 2019.

Table 8. Nutritional Status 5 Points

\begin{tabular}{|l|l|l|}
\hline & N & \% \\
\hline Bad & 6 & 3.9 \\
\hline Less & 14 & 9.0 \\
\hline Good & 108 & 69.7 \\
\hline More & 7 & 4.5 \\
\hline Obesity & 20 & 12.9 \\
\hline Total & 155 & 100 \\
\hline
\end{tabular}

Malnutrition itself can be divided into 2, namely severe underweight (insufficient, BMI <17) and mild underweight (less, BMI = 17-18.4). As many as $3.9 \%$ of schizophrenic patients have poor nutritional status. Patients with obese nutritional status $(\mathrm{BMI}>27)$ were the second most common after good nutrition, namely 20 people $(12.9 \%)$. It indicates that the nutritional status of schizophrenic patients is good, although the textbook says that schizophrenic patients experience decreased appetite, are lazy to eat or refuse to eat.

Table 9. Nutritional Status in Male and Female Patients

\begin{tabular}{|c|c|c|c|c|c|}
\hline & & & & \multicolumn{2}{|c|}{ Gender } \\
\hline & & & & Male & Female \\
\hline \multirow{6}{*}{$\begin{array}{l}\text { Patient } \\
\text { Status }\end{array}$} & \multirow[t]{6}{*}{ Nutritional } & \multirow[t]{2}{*}{ Less } & $\mathrm{N}$ & 14 & 6 \\
\hline & & & $\%$ & $13.5 \%$ & $11.8 \%$ \\
\hline & & \multirow[t]{2}{*}{ Good } & $\mathrm{N}$ & 75 & 33 \\
\hline & & & $\%$ & $72.1 \%$ & $64.7 \%$ \\
\hline & & \multirow[t]{2}{*}{ More } & $\mathrm{N}$ & 15 & 12 \\
\hline & & & $\%$ & $14.4 \%$ & $23.5 \%$ \\
\hline \multirow{2}{*}{\multicolumn{3}{|c|}{ Total }} & $\mathrm{N}$ & 104 & 51 \\
\hline & & & $\%$ & $100 \%$ & $100 \%$ \\
\hline
\end{tabular}

In table 9, it can be seen that the nutritional status of male and female patients for both is mostly good nutrition, namely $72.1 \%$ and $64.7 \%$. Malnutrition in male patients reached $13.5 \%$, while patients with more nutrition reached $14.4 \%$. Nutritional status in female patients of $11.8 \%$ was undernourished, and $23.5 \%$ were overweight.

The room's division according to the degree of the patient's condition can describe the nutritional status of the patient seen from the degree of the patient's condition. However, not all rooms were based on patient's degree condition, and some patients were transferred to another room during the study. The number of patients in each room and their nutritional status can be seen in table 10. The number of patients in each room is different depending on the patient capacity of each room.

Table 10. Nutritional Status of Respondents in Each Room

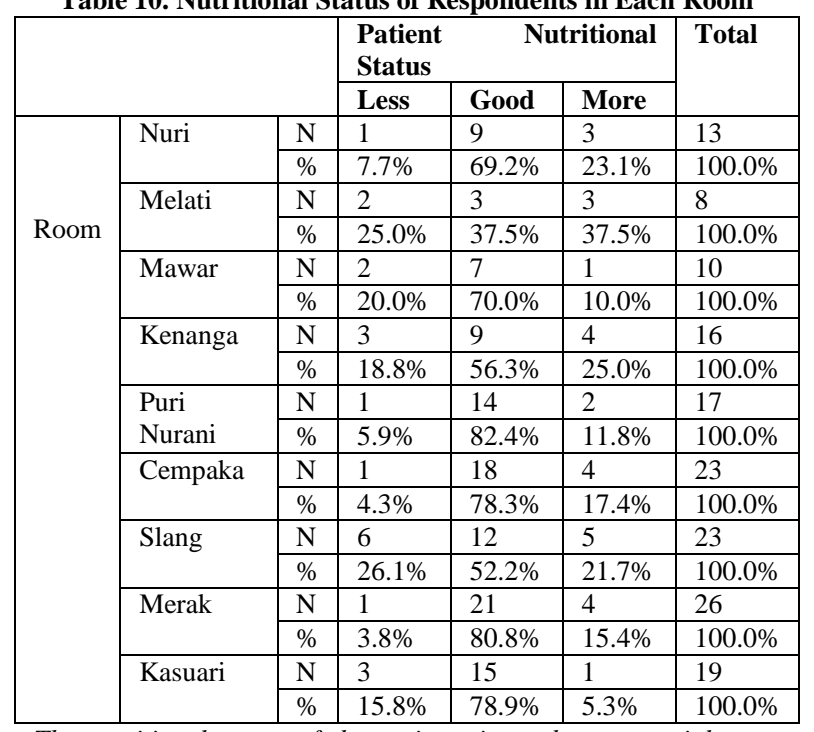

The nutritional status of the patients in each room mainly was good nutrition. Even in the acute and intermediate rooms, most patients are well-nourished.

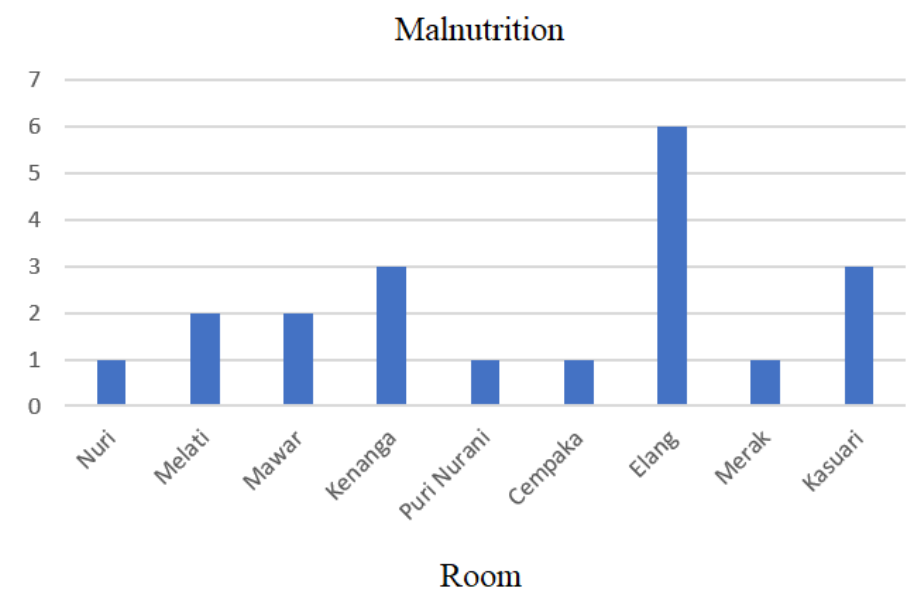

Figure 1. Distribution of Undernutrition 


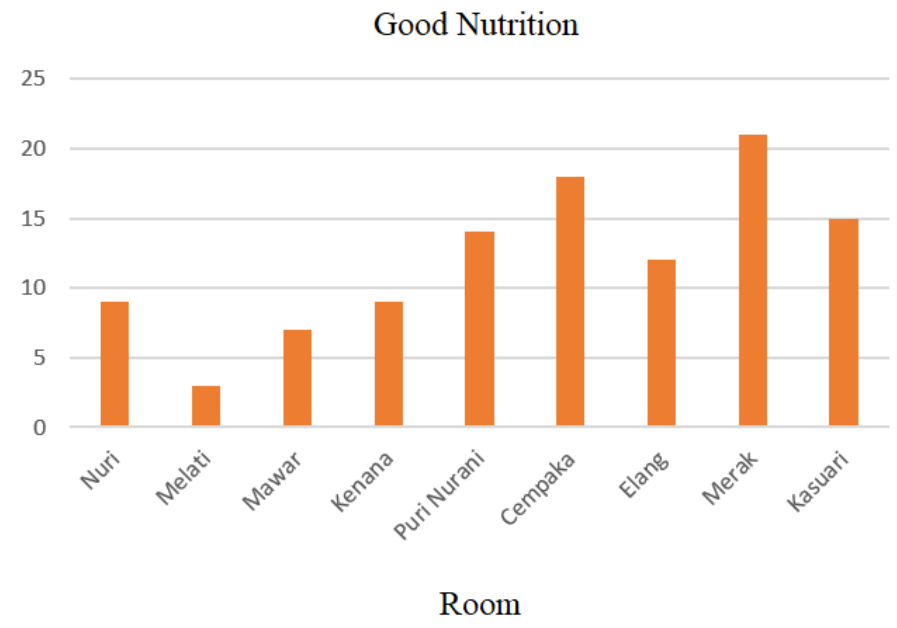

Figure 2. Distribution of Good Nutrition

The most malnourished patients were in the Elang Room (acute patient room), while the most well-nourished patients were in the Merak Room (independent patient room).

Respondent's Food Intake - In this study, the patient's food intake was assessed for five days each breakfast, lunch, and dinner. With the Comstock method or a 6-point visual assessment, food intake is converted into calories and added up. Food waste is considered high if the remaining food is $25 \%$ or more [25]. The rest of the respondents' food can be seen in table 11 .

Table 11. Total Food Residual Food Intake of Respondents

\begin{tabular}{|l|l|l|}
\hline & N & Persentase \\
\hline Tidak ada sisa & 10 & $6.5 \%$ \\
\hline Sisa makanan $<25 \%$ & 135 & $87.1 \%$ \\
\hline Sisa makanan $\geq 25 \%$ & 10 & $6.5 \%$ \\
\hline Total & 155 & $100 \%$ \\
\hline
\end{tabular}

The results in this study were patients who left food $25 \%$ by $6.5 \%$, namely ten people. Ten patients did not leave their food for five days. The highest number were respondents who left food $<25 \%$, which was $87.1 \%$ with a total of 135 people, even though they included good leftovers (not more than or equal to $25 \%$ ).

Leftover meal $25 \%$ indicates a schizophrenic patient eats little. This little habit of eating can affect his nutritional status in the future. The habit of eating less is likely due to symptoms of schizophrenia. Food intake of schizophrenic patients for three meals for five days was calculated the number of calories and calculated the average calories per day. Although the most leftovers left $<25 \%$ of food, the most found calories per day were maximum calories per day. The average calories per day of respondents can be seen in table 12 , and the average intake of macronutrients per day can be seen in table 13 .

Table 12. Average Food Intake of Energy Per Day

\begin{tabular}{|l|l|}
\hline & Calories \\
\hline Average & 1598.28 \\
\hline Most widely & 1825.00 \\
\hline Minimum & 1094.08 \\
\hline Maximum & 1825.00 \\
\hline
\end{tabular}

The average food intake of respondents who have converted into energy is $1598.28 \mathrm{kcal} /$ day. The least energy per day is 1094.08 $\mathrm{kcal}$, while the most are $1825 \mathrm{kcal} / d a y$. In this study, the maximum food intake was all food provided by the nutrition installation.

Table 13. Average Macronutrient Intake per Day
\begin{tabular}{|l|l|l|l|}
\hline \multicolumn{1}{|c|}{} & $\begin{array}{l}\text { Average } \\
\text { Carbs per day } \\
\text { (grams) }\end{array}$ & $\begin{array}{l}\text { Average } \\
\text { protein per } \\
\text { day (grams) }\end{array}$ & $\begin{array}{l}\text { Average } \\
\text { per } \\
\text { (grams) }\end{array}$ \\
\hline Average & 225.075 & 61.414 & 61.835 \\
\hline Minimum & 166.3 & 45.1 & 44.1 \\
\hline Maximum & 243.8 & 65.4 & 66.1 \\
\hline
\end{tabular}

The average food intake of respondents seen from carbohydrates consumed is 225 grams per day. The intake of protein and Fat per day was 61.4 grams and 61.8 grams, respectively. The minimum intake of carbohydrates, protein, and Fat is 166.3 grams, 45.1 grams, and 44.1 grams. Food intake on the nutritional status of respondents - This study wanted to see the patient's food intake for five days in each category of nutritional status. The amount of food consumed by the patient is converted 
into energy, carbohydrates, protein, and Fat. Good food intake can lead to good nutritional status. In this study, it can be seen the nutritional intake in each category of the respondent's nutritional status.

Table 14. Food Intake on the Nutritional Status of Respondents

\begin{tabular}{|c|c|c|c|c|c|c|}
\hline & \multicolumn{3}{|c|}{ Total food waste (\%) for five days } & \multirow[t]{2}{*}{ Total } \\
\hline & & & No leftovers & $<25 \%$ & $\geq 25 \%$ & \\
\hline \multirow[t]{6}{*}{ Patient Nutritional Status } & \multirow[t]{2}{*}{ Less } & $\mathrm{N}$ & 0 & 15 & 5 & 20 \\
\hline & & $\%$ & $0.0 \%$ & $75.0 \%$ & $25.0 \%$ & $100 \%$ \\
\hline & \multirow[t]{2}{*}{ Good } & $\mathrm{N}$ & 9 & 94 & 5 & 108 \\
\hline & & $\%$ & $8.3 \%$ & $87.0 \%$ & $4.6 \%$ & $100 \%$ \\
\hline & \multirow[t]{2}{*}{ More } & $\mathrm{N}$ & 1 & 26 & 0 & 27 \\
\hline & & $\%$ & $3.7 \%$ & $96.3 \%$ & $0.0 \%$ & $100 \%$ \\
\hline
\end{tabular}

This study stated that food waste that was more or equal to $25 \%$ was obtained from respondents with poor nutrition and good nutrition. A total of 5 people with malnutrition left $25 \%$ of food for five days. Likewise, five respondents with good nutrition left $25 \%$ food for five days. Respondents with nutrition are more likely to leave food $<25 \%$ for five days. Respondents who did not leave food were mostly respondents whose nutritional status was good. However, in respondents with more nutrition, $96.3 \%$ left eating $<25 \%$. It can be said that despite excessive nutritional status, food intake is not optimal, which may be caused by negative symptoms of schizophrenia, namely decreased appetite, lazy to eat, or refusal to eat.

The study "Overview of Nutritional Status in Schizophrenic Patients in RSJ dr. Suharto Heerdjan Grogol in 2019 "results from the nutritional status of patients who are assessed from BMI at most being good nutrition. The short period is a confounder in this study. It can be seen in the BMI of patients who were less or more before being treated, which did not change much, so that it was not appropriate to describe the nutritional status of schizophrenic patients. Based on the results of this study, schizophrenic patients were hospitalized at the Mental Hospital dr. Suharto Heerdjan Grogol in October 2019, more men than women. As many as $67.1 \%$ male patients and $32.9 \%$ female patients. According to the epidemiological theory of schizophrenia, the prevalence of schizophrenia is more in men [4]. Although many researchers say, the prevalence of schizophrenia in men and women is the same.

The patient's average height was $161.49 \mathrm{~cm}$, while the patient's average weight was $59.2 \mathrm{~kg}$. The shortest patient's height was $143 \mathrm{~cm}$, while the tallest was $186 \mathrm{~cm}$. The patient's lightest weight was $36.1 \mathrm{~kg}$, while the heaviest was $132.5 \mathrm{~kg}$. The patient's height and weight were calculated according to the BMI formula to determine the patient's nutritional status. Changes in body weight in patients by $16.8 \%$ lost weight, while $83.2 \%$ gained weight. Decreased appetite in the long term will lead to significant weight loss. However, antipsychotic drugs have the effect of increasing appetite and weight significantly [7].

Decreased appetite causes food intake also to decrease; this can be seen in most patients leaving food. Of the 155 people, only ten people left no food for five consecutive days. Of the 145 people who left food, 10 left $25 \%$ or more food for five days. It is following previous research at the Central Mental Hospital in Semarang, patients who left more food than those who finished their food, and research at the Mental Hospital Prof. Dr Soerojo Magelang, i.e. leftover food $25 \%$ of $88.9 \%$ with 16 out of 18 people [26]. As discussed in the previous subchapter, patients at the Mental Hospital dr. The medical staff will persuade Suharto Heerdjan to finish his food, so not many will leave $25 \%$ food.

Nutritional status of schizophrenic patients at the Mental Hospital dr. Suharto Heerdjan Grogol, the majority of good nutrition, is $69.7 \%$. The results of this study 
are different from the previous research conducted in 2011 by Siti Nur Hayati at the Mental Hospital dr. Suharto Heerdjan Grogol. In this study, $30.4 \%$ of the nutritional status of schizophrenic patients was found to be undernourished, which included thin and very thin [27]. Patients with obesity nutritional status (BMI > 27) obtained 20 people (12.9\%). Obesity that occurs can be caused by side effects of using atypical antipsychotic drugs [28].

The respondent's daily food intake was calculated based on breakfast, lunch, and dinner every day for five days analyzed for nutrients using the Nutri survey program. The average food intake of respondents who have been converted into energy is $1598.28 \mathrm{kcal} /$ day. The least energy per day is $1094.08 \mathrm{kcal}$, while the most are $1825 \mathrm{kcal} /$ day. In this study, the maximum food intake was all food provided by the nutrition installation. Six patients had to fast (skip breakfast) for one day in 5 days of collecting data on the respondent's food intake before ECT therapy. A previous study conducted by Winardi at the Semarang Central Mental Hospital showed that most schizophrenia patients (90.4\%) had less than $90 \%$ of the RDA [29].

\section{CONCLUSION}

Based on the results of descriptive observational research on schizophrenic patients at the Mental Hospital, dr. Suharto Heerdjan Grogol in October 2019 can be concluded as the nutritional status of inpatient schizophrenia patients at the Mental Hospital dr. Suharto Heerdjan Grogol in October 2019 had the best nutrition with 108 people $(69.7 \%)$. Therefore, it is expected to do further research with analytical methods to find out the relationship of any factors that can affect the nutritional status of schizophrenic patients and the patients treated for a long time to get better results. In addition, it is also expected to do research using primary data to avoid incomplete data from secondary data and weigh food waste to get more accurate results.

\section{Acknowledgement: None}

\section{Conflict of Interest: None}

\section{Source of Funding: None}

\section{Ethical Approval: Approved}

\section{REFERENCES}

1. Jablensky, A. (2010). The diagnostic concept of schizophrenia: its history, evolution, and future prospects. Dialogues in clinical neuroscience, 12(3), 271.

2. Patel, K. R., Cherian, J., Gohil, K., \& Atkinson, D. (2014). Schizophrenia: overview and treatment options. Pharmacy and Therapeutics, 39(9), 638.

3. Sepalanita, W., \& Khairani, W. (2019). The Effect of Group Activity Therapy with Perceptual Stimulation on the Ability to Control Hallucinations in Schizophrenic Patients. Jurnal Ilmiah Universitas Batanghari Jambi, 19(2), 426431.

4. Nayerifard, R., Zahiroddin, A., Namjoo, M., \& Rajezi, S. (2017). Comparison of metabolic syndrome prevalence in patients with schizophrenia and bipolar I disorder. Diabetes \& Metabolic Syndrome: Clinical Research \& Reviews, 11, S411-S416.

5. Smith, D. J., Langan, J., McLean, G., Guthrie, B., \& Mercer, S. W. (2013). Schizophrenia is associated with excess multiple physical-health comorbidities but low levels of recorded cardiovascular disease in primary care: cross-sectional study. BMJ open, 3(4), e002808.

6. Kuipers, L., Kuipers, E., Leff, J., \& Lam, D. (2002). Family work for schizophrenia. RCPsych Publications.

7. Arkell, J., \& Robinson, P. (2008). A pilot case series using qualitative and quantitative methods: Biological, psychological and social outcome in severe and enduring eating disorder (anorexia nervosa). International Journal of Eating Disorders, 41(7), 650-656.

8. Sutria, E. (2020). Intervention of Nurse Deficit Self Care in The Skizofrenia Patient: Systematic Review. Journal of Nursing Practice, 3(2), 244-252. 
9. Stip, E., Lungu, O. V., Anselmo, K., Letourneau, G., Mendrek, A., Stip, B., ... \& Bentaleb, L. A. (2012). Neural changes associated with appetite information processing in schizophrenic patients after 16 weeks of olanzapine treatment. Translational psychiatry, 2(6), e128-e128.

10. Bourre, J. M. (2006). Effects of nutrients (in food) on the structure and function of the nervous system: update on dietary requirements for brain. Part 1: micronutrients. Journal of nutrition health and aging, 10(5), 377.

11. Kagura, J. (2011). Association between infant nutrition and later body composition (Doctoral dissertation).

12. Brinkman, H. J., De Pee, S., Sanogo, I., Subran, L., \& Bloem, M. W. (2010). High food prices and the global financial crisis have reduced access to nutritious food and worsened nutritional status and health. The Journal of nutrition, 140(1), 153S-161S.

13. Hanssen, M., Peeters, F., Krabbendam, L., Radstake, S., Verdoux, H., \& Van Os, J. (2003). How psychotic are individuals with non-psychotic disorders?. Social psychiatry and psychiatric epidemiology, 38(3), 149-154.

14. Schomerus, G., Matschinger, H., \& Angermeyer, M. C. (2014). Causal beliefs of the public and social acceptance of persons with mental illness: a comparative analysis of schizophrenia, depression and alcohol dependence. Psychological medicine, 44(2), 303-314.

15. Torrey, E. F., \& Yolken, R. H. (2019). Schizophrenia as a pseudogenetic disease: A call for more gene-environmental studies. Psychiatry research, 278, 146150.

16. Rubeša, G., Gudelj, L., \& Kubinska, N. (2011). Etiology of schizophrenia and therapeutic options. Psychiatria Danubina, 23(3.), 308-315.

17. Sakkas, H., Bozidis, P., Touzios, C., Kolios, D., Athanasiou, G., Athanasopoulou, E., ... \& Gartzonika, C. (2020). Nutritional status and the influence of the vegan diet on the gut microbiota and human health. Medicina, 56(2), 88.
18. Kushi, L. H., Doyle, C., McCullough, M., Rock, C. L., Demark- Wahnefried, W., Bandera, E. V., ... \& American Cancer Society 2010 Nutrition and Physical Activity Guidelines Advisory Committee. (2012). American Cancer Society Guidelines on nutrition and physical activity for cancer prevention: reducing the risk of cancer with healthy food choices and physical activity. CA: a cancer journal for clinicians, 62(1), 30-67.

19. Mancuso, C., Izquierdo, A., Slattery, M., Becker, K. R., Plessow, F., Thomas, J. J., ... \& Misra, M. (2020). Changes in appetite-regulating hormones following food intake are associated with changes in reported appetite and a measure of hedonic eating in girls and young women with anorexia nervosa. Psychoneuroendocrinology, 113, 104556.

20. Borji, M., Moradi, M., Otaghi, M., \& Tartjoman, A. (2018). Relationship between nutritional status, food insecurity, and causes of hospitalization of children with infectious diseases. Journal of Comprehensive Pediatrics, 9(2).

21. Earthman, C. P. (2004). Evaluation of nutrition assessment parameters in the presence of human immunodeficiency virus infection. Nutrition in clinical practice, 19(4), 330-339.

22. Goli, S., Rammohan, A., \& Singh, D. (2015). The effect of early marriages and early childbearing on women's nutritional status in India. Maternal and child health journal, 19(8), 1864-1880.

23. Landecker, H. (2011). Food as exposure: Nutritional epigenetics and the new metabolism. BioSocieties, 6(2), 167-194.

24. Ferro-Luzzi, A. (2003). Keynote Paper: Individual food intake survey methods. Meas. Assess. Food Deprivation Undernurition. Rome: Food and Agriculture Organization of the United Nations.

25. Lou, Y. (2018). Systematic analysis of food visual estimation methods and applications in school lunch (Doctoral dissertation, Iowa State University).

26. Setiati, S., \& MEpid, S. P. (Eds.). (2014). Internal medicine. Interna publishing. 
27. Maulina, M., Rahayu, M. S., \& Yuziani, Y. (2017). Correlation of total cholesterol to HDL ratio with prediction of acute ischemic stroke outcome stroke. Universitas Malikussaleh, 2(1): 59-71.

28. Saputri, A. I., \& Maulina, M. (2018). Relationship between lipid profile and length of stay of ischemic stroke patients at the Regional Public Service Agency of the Cut Meutia General Hospital, North Aceh Regency. Averrous: Jurnal Kedokteran dan Kesehatan Malikussaleh, 2(1), 90-102.
29. Arifnaldi, M. S. (2014). The relationship between triglyceride levels and the incidence of ischemic stroke in RSUD Sukoharjo (Doctoral dissertation, Universitas Muhammadiyah Surakarta).

How to cite this article: Adriani A. Overview of nutritional status in schizophrenic patients at Dr. Soeharto Heerdjan Grogol Hospital in 2019. Int J Health Sci Res. 2021; 11(8): 225236. DOI: https://doi.org/10.52403/ijhsr. 20210832 